\title{
THE EFFECT OF USING COMPOSITE PICTURES ON READING COMPREHENSION ACHIEVEMENT
}

\author{
FATMA DEWANI HARAHAP \\ Program Studi Sistem Informasi, Universitas Nahdlatul Ulama Sumatera Utara \\ Email: Fatmadewaniharahap@yahoo.com
}

\begin{abstract}
Abstrak
Reading Comprehension adalah kemampuan membaca teks, mengolahnya dan memahami maknanya. Itu bergantung pada dua, kemampuan yang saling berhubungan: Membaca kata mampu memecahkan kode simbol pada halaman dan pemahaman bahasa mampu memahami arti kata dan kalimat. Pada kenyataannya, siswa pada umumnya merasa bosan dan tidak termotivasi dalam belajar Bahasa Inggris terutama dalam keterampilan membaca karena Bahasa Inggris berbeda dengan bahasa Indonesia sehingga siswa mengalami kesulitan dalam memahami teks bacaan Bahasa Inggris. Mereka tidak tahu arti dari beberapa kata dalam teks. Oleh karena itu, peran guru menjadi penting dalam proses belajar mengajar khususnya dalam pengajaran membaca. Oleh karena itu, media yang tepat harus dipilih untuk memotivasi siswa mereka tidak hanya untuk membaca teks tetapi juga memahami apa yang mereka baca. Salah satu media yang dapat digunakan dan diterapkan oleh guru adalah Gambar. Gambar Gabungan adalah gambar tunggal besar yang menunjukkan pemandangan di mana sejumlah orang dapat terlihat melakukan beberapa hal. Dengan demikian, untuk mengetahui ada tidaknya pengaruh yang signifikan penggunaan Gambar Komposit terhadap prestasi membaca pemahaman; Komposit Gambar digunakan sebagai media dalam pengajaran membaca dalam penelitian ini.
\end{abstract}

Kata Kunci: Reading comprehension, Composite Picture

\begin{abstract}
Reading Comprehension is the ability to read text, process it and understand the meaning. It relies on two, interconnected abilities: Word reading be able to decode the symbols on the page and language comprehension being able to understand the meaning of words and sentences. In fact, students generally feel bored and unmotivated in learning English especially in reading skill because English is different from Indonesian so that the students have difficulty in understanding reading English text. They do not know the meaning of some words in the text. Therefore, the teacher's role becomes important in the teaching and learning process especially in teaching reading. Therefore, appropriate media should be chosen to motivate their students not only to read the text but also comprehend what they read. One of the media that can be used and applied by the teacher is Composite Pictures. A Composite Picture is a large single picture which shows a scene in which a number of people can be seen doing several things. Thus, to know whether or not there was a significant effect of using Composite Pictures on reading comprehension achievement; Composite Pictures was used as media in teaching reading in this research.
\end{abstract}

Key Words: Reading comprehension, Composite Pictures 


\section{INTRODUCTION}

Language is an important part of human for communication. By language, people able to convey ideas, mind, opinion and feeling. Hence, it is unquestionable that English as the main language is used to get much important information on any fields of study such as, science, medicine, technology, academic field, publication, computer, networking, trading, education and many more.

English has been taught as a local content subject at elementary school and as a compulsory subject in Junior and Senior High School up to University level. According to Tonkin (2003:16) English as an international language is learnt by some countries as a second language and in other countries as a foreign language.

There are four English language skills that have to be taught in Indonesia namely listening, speaking, reading and writing. The four skills should be mastered by the students. From those four skills, reading is one of the skills that has an important role in English language teaching. Reading is a process that demands the students to understand group of the words in the form of a certain unit and the meaning of each word will be known (Tarigan, 1990:7)

Based on the School Based Curriculum, teaching reading at Junior High School has some purposes that is to find out the main idea of the text and to find out the general and the specific information of the text. Therefore, it can be said that comprehending the text is required by the students to gain the meaning of the text. This research focused on finding the general information and finding the specific information of descriptive text. This consideration was based on the syllabus of the seventh grade students of Junior High School mentioning that there are two texts that should be taught at the seventh grade namely Procedure text and Descriptive text.

In this research, the students' scores of reading comprehension test were indicated by the students' reading comprehension achievement after given different instruction. The treatment was given to the experimental group that was using Composite Pictures and control group was taught by using question-answer method (without using Composite Pictures).

According to Wright (1989:136), the use of pictures may be a good beginning point to help the students to develop their reading skills. Pictures represent the nonverbal sources of the information which helps students to predict what the text might be about. The capability to predict helps the students to recognize meaning more quickly than if they have to sort it out solely from what they hear or read. Wright (1989:193203) also states, there are many kinds of pictures that can be used in teaching learning activities namely individual pictures, picture in series, and composite pictures.

In this research, the kinds of picture that was used as the media in teaching reading comprehension was Composite Pictures. The researcher thought that the students could see many activities in the picture and it made them get more information from the picture. The composite pictures used were suitable for the whole class because they had large sizes. Thecomposite pictures can be taken from textbook, calendar, 
tourist poster, or from the internet. In this research, the composite pictures were taken from internet.

There are some stages in teaching reading activities in each stage are described below:

1.The teacher shows to the students the composite picture which is related to the topic and the students discuss what they think about the picture.

2.The teacher asks the questions to help the students focus on the topic.

3.The teacher gives the students the reading text and the task of reading comprehension.

4.Then, the teacher as a model reads the reading text and asks the students to pay attention.

5.After that, the teacher asks the students to read the text loudly again and then reread independently, underlined the difficult words and find the meaning of underline word by using composite pictures

6.The teacher asks the students to do the task by using the composite picture as media.

Wright (1989:139) states that the written text describes the content of the picture, with the picture illustrating the meaning of the new language. In this case, picture especially the composite picture can help the students comprehend the reading text, if there is a "new" language, it can be understood because the picture illustrates the meaning. Besides, Composite pictures have the strengths and the weaknesses. The strengths of composite pictures are as follows.

1.Composite pictures enable students to see places, people and events that they would otherwise not see because of factors like distance, time and cost (Yunus,1981:49).

2.In one composite picture we can get a lot of information.

3.Provide a clue to the meaning of details, either introducing it to the learners for the first time or reminding them of it.

4.Because of their size, composite pictures are one of the appropriate media for wholeclass teaching rather than individualized learning or group work although there is a tendency on the part of teachers to over-use such pictures in their effort to use the content to the maximum.

The weaknesses of composite pictures are:

1.A limited number of composite pictures are available commercially.

2.It is too difficult to create composite pictures inlarge size because it is time consuming.

After knowing the weaknesses of composite pictures above, the researcher triedto find the solution to handle this by creative on making the composite picture since the researcher had a skill in combining pictures into excellent composite pictures. Then the composite pictures were shown through the LCD projector.

\section{RESEARCH METHODS}

The design of this research was Experimental research because the objective of this research was to know whether or not the use of Composite Pictures had a 
significant effect on the seventh grade students' reading comprehension achievement at SMPN 1Percut Sei Tuan. Quasi-experimental research with post-test only control group design was applied by involving two groups, the experimental and the control groups. Homogeneity test was used to know the homogeneity of the population. The scores of the homogeneity test were then analyzed by using ANOVA (Analysis of Variance Computation) Formula. After analyzing the result of the test, the two classes were chosen as the experimental group (VII B) and control group (VII C). The total number of students for both classes was the same that was 36 students. The two classes received different instruction where the experimental group received instruction that was taught reading comprehension by using Composite Picture whereas the control group received instruction that was taught reading comprehension without Composite Pictures. After that, administering a try-out of the test material to one of the other seventh grade classes which was not included as the research subjects to know whether or not the test items conformed with the students' level of comprehension, the instruction of the test was clear, and the time of the test was appropriate. Reading comprehension test was given to both groups to find out the difference of the reading comprehension achievement, then comparing the result of both groups by using t-test formula. The last, drawing conclusions after analyzing the test scores to answer the research question.

The design is presented as follows.
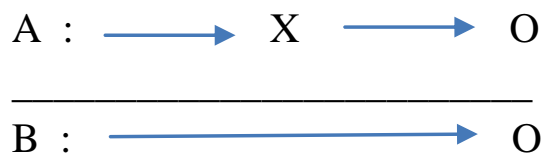

Notes:

A: Experimental Group

B: Control Group

$\mathrm{X}$ :Treatment

O: Post Test

The homogeneity test was administered on October 26th, 2021. The homogeneity test was administered to know whether the 6 classes were homogeneous or not. The results of homogeneity test were analyzed statistically by using ANOVA formula, the result of statistical computation was 17.82 while the value of F-table in 5\% significant level was 52.5.From the calculation above, it was known that F-computation was lower than that of F-table. Therefore, it can be concluded that there was no significant difference mean of the five classes. In other words, the population was homogenous and the samples could be taken randomly from any classes of the population by using lottery. Based on the lottery, two classes were chosenas research sample, VII B as the experimental group with the mean score 70.11 and VII C as the control group with the mean score 73.40 .

Before conducting the reading comprehension test, the try out was conducted Oktober 20th, 2021. It was given to one of the other seventh grade classes which was not included as the research subjects. From the result, it was known that the range of 
difficulty index was from 0.44 up to 0.66 . Itcould be concluded that the test items were neither too easy nortoo difficult. Thus, the researcher did not need to revise the test items.Then, Split half Odd-Eventechnique was applied to calculate the reliability coefficient. The reliability coefficient was analyzed from the scores of the try out. From the calculation, it was found that the reliability coefficient of a half test was 0.67 . Then, it was continued by finding the reliability coefficient of the whole test by using Spearman Brown Formula. From the calculation of Spearman Brown formula, the reliability coefficient of the whole test was 0.80. Djiwandono (1996:154) states the reliability coefficient of the whole items that was 0.80 was categorized as high correlation $(0.70-0.89)$ and the test was considered reliable. It means that the researcher did not have to make any changes of the test items, and the test items of thepost test could be administered to the real test

From the result, it was known that the mean score (M) of the experimental group was 75.91 and the control group was 59.52 and the t-test value was 3.016 and the $\mathrm{t}$ table.of 5\% and the degree of freedom 70 was 2.00. The result of mean scores on the experimental group was higher than that of the control group and also the t-test value was higher than that of t-table. It means that the null hypothesis (Ho): "The use of Composite Pictures has a significant effect on the seventh grade students' reading comprehension achievement at SMPN 1 Percut Sei Tuan" was rejected. On the other hand, the alternative hypothesis (Ha): "The use of Composite Pictures has a significant effect on the seventh grade students' reading comprehension achievement at SMPN 1 Percut Sei Tuan" was accepted.

Based on the result above, it could be stated that Composite Pictures significantly affected the students' reading comprehension achievement at SMPN 1 Percut Sei Tuan.

\section{RESEARCH FINDING AND DISCUSSIONS}

In this research, the reading test was applied to get data about the students' reading comprehension achievement. The total number of the test items was 20 in the form of multiple choice consisting of 8 items of identifying general information and 12 items of identifying specific information. After the result of reading comprehension test had been analyzed.It could be reported that Composite Pictures gave significant effect to the seventh gradestudents of SMPN 1 Percut Sei Tuan. It was shown by the result of the reading comprehension test that the value of t-computation was higher that the value of t-table $(3.016>2.00)$.

Theoretically, the result finding of the research was in line with the expert's idea that teaching reading comprehension using Composite Pictures was one of the effective media for students in comprehending the text easily because it has a lot of information. Usman (1995:27) explains that the learning can be more successful if it involves some kinds of media than without having one. It means that media are needed in teaching 
learning process to make the students more interested in the material taught by the teacher.

Relating to the previous research findings, the results of this research revealed similar facts that the composite picture was effective to increase the students' reading comprehension achievement. This was proved by previous researchesconducted by Anggraini (2011) proving that the use of composite pictures could affect the seventhgrade students' reading comprehension achievement at SMPN 4 Bondowoso in the 2011/ 2012 Academic Year.She found that the students who were taught reading through Composite Pictures gained better reading achievement than those who were taught reading by using Question and Answer without Composite Pictures $(71,88>64,34)$. Another research done by Ariyanto (2003) also proved that the use of Composite Pictures could improve students' reading comprehension achievement covering getting the main idea of the reading text. The improvement could be seen from the results of the reading test in the second cycle $M=70.26$ that was better than that in the first cycle $\mathrm{M}=61.84$

From the above discussion, it could be seen that the result of this research was not different from that of the previous research in helping the students to comprehend the reading text effectively by using Composite Pictures. In other words, the research showed that the application of using Composite Pictures affected the students' reading comprehension achievement. The statistical value proved that there wasa significant effect of using Composite Pictures on the seventh grade students'reading comprehension achievement at SMPN 2 Tenggarang Bondowoso. Based on the result ofthe previous research and this research, Composite Pictures gave significant effect to the seventh grade students at SMPN 1 Percut Sei Tuan.

\section{CONCLUSIONS AND SUGGESTIONS}

Based on the results of the data analysis and the hypothesis verification discussed in the previous chapter, it can be concluded that the use of Composite Picture has a significant effect on reading comprehension achievement of the seventh grade students at SMPN 1 Percut Sei Tuan.

Considering the result of the research, the researcher proposed some suggestions. 1) It is recommended for the English teachers to use Composite Pictures as the media of teaching English especially in teaching reading comprehension skill. Hopefully, the English teachers will use Composite Pictures not only in teaching reading comprehension but also in teaching the other language skills and language components. 2) It is hoped that the result of this research can be used as a reference and information for future researchers to conduct further research dealing with the use of composite pictures by using a different language skills or components. 


\section{REFERENCES}

Anggraini, D. 2011. "The Effect of Using Composite picture on Reading Comprehension Achievement of the $7^{\text {th }}$ Grade Students at SMPN 4 Bonsowoso." Published Thesis. Jember: Universitas Jember.

Ariyanto, R.2003. " The Use of Pictures in Getting The Main Idea Of The Text To Developed Students Reading Comprehension of SMK 1 Jember." Unpublished. Thesis. Jember: Universitas Jember.

Depdiknas.2006. Kurikulum Tingkat Satuan Pendidikan (KTSP) Mata Pelajaran Bahasa

Inggris untuk SMP/MTS Jakarta: Depdikbud

Djiwandono, M. S. 1996. Tes Bahasa Dalam Pengajaran. Bandung: ITB Bandung.

McMillan, L.H.1992. Educational Research: Fundamental for Consumers. New Yoek:

Harper Collins Publishers

Tarigan, H.G. 1990. Membaca Sebagai Suatu Keterampilan Berbahasa. Bandung: PT. Angkasa.

Usman, M.U. 1996. Menjadi Guru Profesional. Bandung: PT. Remaja Rosdakarya. Wright, A. 1989. Pictures for Language Learning. Cambridge Press.

Tonkin, H. 2003. Language and Society.http://www.globaled.org/issues/178F.pdf. [March 9, 2010]. 